\title{
The STS-Constructivist Reform: Some Discordant Notes
}

\author{
B.G. Nworgu $\mathbf{1}$ \\ Department of Science Education, University of Nigeria, \\ Nsukka, Enugu State \\ and \\ Robert E. Yager \\ Science Education Center, University of Iowa, U.S.A.
}

\begin{abstract}
It would appear that as many more voices join in the advocacy for STSconstructivist Reform in science teaching/learning, more discordant notes are emitted. The purpose of the paper therefore, was to spotlight some of these discordant notes emitted in the course of the on-going reform advocacy. Specifically, three of such discordant notes bordering on focus, status, and initiation of the reform are identified. After a critical examination of the seemingly conflicting views on these issues, and drawing from relevant underlying theoretical constructs, more rational, realistic and sustainable viewpoints are synthesized.
\end{abstract}

\section{Introduction}

Polarization of views or dissension is not an uncommon feature of academic or intellectual debates. Indeed, knowledge growth has benefited immensely from such polarizations or dissensions, which sometimes manifest in competing schools of thought. The on-going STS-Constructivist dialogue ought not to be an exception. It is not to be expected that all will speak with a uniformity of voice on issues pertaining to the reform. Even among its protagonists or proponents, it will be a rare expectation, talk-less among its antagonists or opponents.

In a situation such as this, while the antagonists of the reform try to launch attacks at the propositions of the protagonists, the later will strive to debunk such criticisms or attacks. This process ignites a network of intellectual crossfire which will illuminate and brighten the whole terrain of the debate, particularly, the dark corners. This is positive and beneficial to scholarship.

Against this background, criticisms or dissentions coming from outside a given school of thought, are not necessarily discordant notes. However, if those who profess to belong to the same school of thought, send forth different and inconsistent signals to the intellectual community, or worse, still, if the positions maintained on certain issues are unclear and confusing then there is an ominous sign. Such inconsistencies or confusion arising from within - which in the context of this paper, have been referred to as discordant notes - can be fatalistic. The antagonists of the reform can

\footnotetext{
${ }^{1}$ Note: All correspondence to the first author
} 
capitalize on them to deal deadly blows on whatever structures we think we may have erected.

\section{Purpose}

In essence, the main thrust of this paper is to: (1) spotlight some of the discordant notes in the STS-Constructivist propositions; (2) examine these discordant notes critically; and (3) suggest what may be a more rationale, realistic and sustainable posture for the STS-Constructivist community with respect to the issues in question.

\section{The discordant Notes}

In this section, we shall examine these issues over which there appears to be considerable confusion or lack of clarity in the position of the advocates of STS-Constructivist reform. These are as follows:

1. What is the focus of STS-Constructivist pedagogy?

2. Current discussions of the STS-Constructivist reform tend to leave one in doubt as to the real focus of the reform. Four accounts of the reform which typify this situation are those of Lutz (1996), Myers (1996), Liu and Yager (1996) and Penick and Bonnestetter (1996) Lutz, in her account, gives the picture of a pedagogy which focuses only on process and not on product. According to her "an STS teaching strategy focuses on processes, not on products". (p.41).

Myers' account tends to agree in all essential details with Lutz's view. This is clearly born out of his assertion that "the STS approach - though not focusing on concept mastery - results in..." (p.56). Yet in another account, Liu and Yager opine that:

The STS has been identified by the National Science teachers Association, Project 2061: Science for all Americans and with the NSTA/NSF Project: Scope, Sequence and Coordination (SS\&C) as one with great potential for meeting the first three goal clusters advanced by project synthesis, namely, personal needs, social issues and career awareness (p.151).

In their own account, Penick and Bonnstetter (1996) posited that:

STS teachers are not content with students just knowing words and skills; they insist that words be used to justify, defend, or clarify larger concepts or actions. For many students, they must apply their knowledge before it truly becomes a part of them. Effective STS teachers are never satisfied with content knowledge alone (p.169).

These four accounts are somewhat conflictual in what they present as the focus of STS-Constructivist pedagogy. The first two (Lutz and Meyers) tend to give the impression that STS-Constructivist pedagogy is not concerned with the development of content knowledge. They define a uni-dimensional focus (i.e., process only) for STS-Constructivist pedagogy. This does not only create an erroneous picture of the reform, it is indeed capable of drawing sharp criticisms from the antagonists of the reform (see Shamos, 1993).

The last two accounts (Liu and Yager, and Panick and Bonnstetter) give a better and more representative picture of the reform's focus. They correctly define a multi-dimensional focus for the reform in terms of the development of content knowledge, process skills, attitudes, applications and real-life 
connections, etc. However, they still fall slightly short of providing a complete picture of STS-Constructivist focus.

For us, we see STS-Constructivist focus as extending to all the four goal clusters as identified in the Project Synthesis (Harms, 1977), namely: (1) personal needs; (2) societal needs: (3) career awareness/choice; and (4) preparation for further study. To limit the focus of the reform to only the first three clusters is to circumscribe the vision and projects of a reforms narrowly that has been described as "Mega Trend" and/or a "Paradigm Shift" (Yager, 1996:13). Indeed if "all reasonable projections agree on the universal penetrations of STS as K-12 and college-level approach to course structure and teaching approach throughout formal academia" as argued by Yager and Roy (1993:12), it becomes evident that the focus of the reform should and does extend to the fourth goal cluster-preparation for further academic study.

Alternatively, the focus of the reform can also be described more specifically in terms of the six (6) domains used in the Iowa Chautauqua Model - a model which has been widely used in initiating the STS-Constructivist pedagogy in the U.S. schools.

The six (6) domains essentially derive from the four goal clusters of Project synthesis. They include:

a) Concept Domain - Mastery of scientific content;

b) Process Domain - Acquiring science process skills;

c) Application and Connection Domain - Using the science concepts and process in new situation;

d) Creativity Domain - Improving in quantity and quality of questions, possible explanations, and predicted consequences;

e) Attitude - Developing more positive feelings concerning usefulness of science, science study, science teachers and careers;

f) World-View - Understanding of and ability to use basic science (i.e., questioning, explaining and testing objects and events) in the nature world.

A worthwhile program of STS-Constructivist pedagogy should focus on all these domains. No domain ought to be emphasized more or less than the other.

\section{What is the status of STS-Constructivist Reform?}

Another apparent conceptual crisis in the advocacy for STS-Constructivist reform has to do with its status. Is it a new science curriculum with a definite structure or what? This is one area that has been attacked vigorously by critics of the reform. For instance, Shamos (1998) calls this an identity crisis. According to him,

STS has a serious identity problem....still it lacks a clearly defined structure on which to build such a curriculum; nor is to apparent that it will be possible to establish such a structure in the foreseeable future, because of the conflicting views that surround the STS movement (pp.66$67)$. 
As a matter of fact, the STS-Constructivist approach could evolve into a curriculum as in the case of Science and Society (Lewis, 1981), and Science in Social Context (SISCON) (Solomon, 1983), both in the United Kingdom or PLON in the Netherlands (Eijkelhof, Boeker, Raat and Wijnbeek, 1981), and Science Plus in Canada (A ScP, 1986). However, the fear in holding this view of the STS-Constructivist reform is that it is bound to return as to the status quo. It may end up in students and their teachers relying absolutely on such a curriculum and this will defeat the raison deter for embarking on the reform. This is perhaps the strongest reason against the advocacy for a STS-Constructivist curriculum or textbook not that there is no structure for doing so as Shamos (1993) suggested.

There is also another reason why this is not necessary. There really have not been problems with the existing science content or topics per se. The problem has been with the mode of implementing such content. All the arguments against the traditional instructional setting science, border in the sterile and unproductive nature of the transmission mode adopted within such a setting (Nworgu, 1996, 1999) and not on the content being implemented. Therefore, it seems rational enough to use that the STSConstructivist reform which emerged in response to the above specific concern, should have a clear mandate arising from its status as a new approach to implementing science instruction (Liu and Yager, 1996; Bonnstetter and Pedersen 1993). The characteristics of this approach and the goals it should accomplish have been elaborated and well delineated in Yager (1993 and 1996).

\section{How should an STS-Constructivist lesson be initiated?}

Another issue that needs to be addressed and clarified is how an STSConstructivist lessons should be initiated. Certain accounts of how such lessons are initiated tend to generate some myth over the whole enterprise. Some of these accounts give the impression that STS-Constructivist lessons are initiated through "magical" or 'sudden' occurrences of a natural event or phenomena. The occurrence of such an event will then evoke a spontaneous reaction from the students. Others create a scenario where all the students arrive for a science lesson with a consensus view about what issues(s) or problem(s) to investigate. To drive home this point, we shall consider and analyze two of such accounts - one by Lutz (1996) and the other by Wilson and Livingston (1996).

Lutz's Account

A ninth-grade chemistry class was being distracted by the particularly violent rainstorm going on outside the window. The teacher recognized the wisdom of allowing the students to watch the torrents....The students and the teacher gathered, talking at the rear of the room and watched the storm. One of the students asked about the acid content in the rain. Taking advantage of the students' natural curiosity (a fine example of "the teachable moment"), the teacher used this question to launch an STS investigation about the acid rain (p.46).

Wilson and Livingston's Account

An example of focusing on science process skills was found in the ninth grade physical science program of City High (Iowa City, Iowa). The chemistry unit began with students 
looking at the chemicals found in products. Students were surprised at the amount of preservatives, flavor enhance's, and the claims advertised by the products. As the students investigated more and more products, their initial concern became amplified and the classroom took a student-centered direction. Their concern ultimately developed into the decision to initiate a full scale "Consumer Reports" investigation of various products (p.65).

These two accounts raise a number of fundamental concerns. First, should STS-Constructivist lessons wait until there is a fortuitous occurrence as in the case of the "particularly disturbing rainstorm? Second, if there hadn't been this "particularly disturbing rainstorm", does it mean that an STSConstructivist teacher can not initiate instructions on acid rain? Third, suppose no student raised any questions at all, (and this does not have a remote possibility), would such an opportune moment (a teachable moment) go untapped? Forth, in the case of Wilson and Livingston's account, how did the products find their way into the learning environment? Fifth, how did it come to be that, all the students in the class got attracted to the same issue or problem - the chemical content of the products?

The two accounts in question and others similar to them, tend to give the impression that lessons in the STS-Constructivist setting have a spontaneous and/or mysterious beginning. They try to hide or conceal the teacher's role in initiating or facilitating the initiation of such lessons. This role is not direct or dictatorial; rather, it is facilitative and subtle but quite significant. It may be in the form of questions which will challenge the students to raise issues, ask questions or identify problems. It may be in the form of creating a stimulating and enabling environment which can challenge the curiosity and creative energies of the students.

We have chosen to refer to these facilitative and subtle but significant roles of the teacher in initiating an STS-Constructivist lesson as "teacher prompts". (compare this with the computer prompt). It is certain that the main focus of any STS-Constructivist lesson is on students personal activities which result in their construction of re-construction of scientific knowledge, in a context that shows clearly the usefulness of the new knowledge in solving personal and social problems using appropriate technology. Our contention is that the idea of an STS-Constructivist lesson being initiated via teacher prompts is more viable than the idea that it is initiated through spontaneous, sudden or 'mysterious' events. The later idea does not only diminish the significance of the teacher in the reform, it will result in a void with respect to the context of students activities. On the other hand, the idea of the "teacher prompt" creates the needed context for the students activities that will follow and does not in any way diminish the significance of either the student and his actions or the teacher in the STSConstructivist setting.

\section{Conclusion}

There is no doubt that many more voices are joining in building a strong and persuasive advocacy for STS-Constructivist reform in science teaching and learning. The movement has become globalized. Research evidence from several sources is now available to convince anyone who cares that the 
reform is both viable and feasible. Notwithstanding what may appear to be conflicting views within the advocacy itself, the antagonists of the reform even concede that it has obvious merits. It is certain that the reform has a multi-dimensional focus and a definite status as an innovative approach to science instruction/teaching. It guarantees the student a desirable level of autonomy necessary and sufficient for him to construct his own learning. For the teacher, his/her role is converted to an indirect but significant one. This is evident from the indispensable role teacher prompts are bound to play in the initiation of STS-Constructivist lessons.

\section{Reference}

Atlantic Science Curriculum Project (1986). SciencePlus I. Toronto: Harcourt Brace.

Bonnstetter, R.J. Pedersen, J.E. (1993). The Jurisprudential Inquiry Model for STS. In Yager, R.E. (ed). What research says to the science teacher, Volume 7. Washington, DC: National Science Teachers Association.

Eijelhof, H.M.C., Boeker, E.; Raat, J.H.; \& Wijnbeek, N.J. (1981). Physics in Society. Amsterdam: VU-Bookshop.

Harms, N.C. (1977). Project Synthesis: An interpretative consolidations research identifying needs in natural science education. (A proposal prepared for the National Science Foundation). Boulder: University of Colorado.

Lewis,J. (1981). Science and society. London: Heinemann and Association for Science Education.

Liu, Chin-Tang \& Yager, R.E. (1996). An STS approach accomplishes greater career awareness. In Yager, R.E. (ed.). Science/Technology/Society as reform in science education. Albany: State University of New York

Lutz, M. (1996). The congruency of the STS approach and constructivism. In Yager, R.E. (ed.) Science/Technology/Society as reform in science education. Albany: State University of New York.

Myers, L. (1996). Mastery of Basic Concepts. In Yager, R.E. (ed.). Science/Technology/Society as reform in science education. Albany: State University of New York.

Nworgu, B.G. (1996). Teaching for Conceptual understanding in physics: A Conceptual Change Instructional Model. A lead paper presented at the 37th Annual conference of the Science Teachers' Association of Nigeria at Uyo, 12-17 August.

Nworgu, B.G. (1999). Post-positivistic developments: Challenges to contemporary STM teacher education. A guest/special lecture to the First National Conference of the Faculty of Education, ENUGU State University of Science and Technology, 8-11 September.

Penick, J.E. \& Bonnstetter, R.J. (1996). Different goals, different strategies: STS teachers must reflect them. In Yager, R.E. (ed.0 
Science/Technology/Society as reform in science education. Albany: State University of New York.

Shamos, M.H. (1996). STS: A time for Caution. In Yager, R.E. (ed.) What research says to the science teacher, volume 7. Washington, DC: National Science Teachers Association.

Solomon, J. (1983). Science in social content (SISCON). United Kingdom: Basil Blackwell and Association for Science Education.

Wilson, J. \& Livingston, S. (1996). Process skills enhancement in the STS Classroom. In Yager, R.E. (ed.) Science/Technology/Society as reform in science education. Albany: State University of New York

Yager, R. E. \& Roy, R. (1993). STS: Most pervasive and most radical of reform approaches to science education. In Yager, R.E. (ed.) What research says to the science teacher. Washington, DC: National Science Teachers Association.

Yager, R.E. (1996). History of STS as reform in the United States. In Yager, R.E. (ed.) Science/Technology/Society as reform in science education. Albany: State University of New York.

Yager, R.E. (ed.) (1993). What research says to the science teacher, volume 7. Washington, DC: National Science Teachers Association 